\title{
Associations between coronary artery disease, aneurysm and ectasia
}

\author{
Cengiz Ovalı ${ }^{1}$, Baktash Morrad ${ }^{2}$ \\ ${ }^{1}$ Cardiovascular Surgery Department, Medical Faculty, Eskisehir Osmangazi University, Eskisehir, Turkey \\ ${ }^{2}$ Department of Cardiology, Parkhayat Akşehir Hospital, Afyonkarahisar, Turkey \\ Kardiochirurgia i Torakochirurgia Polska 2017; 14 (3): 158-163
}

\begin{abstract}
Aim: Investigation the frequency and contribution of coronary artery aneurysm/ectasia in addition to their correlation with coronary artery disease (CAD).

Material and methods: We retrospectively evaluated the coronary angiography records of 6500 adult consecutive patients, and 418 of them were met inclusion criteria and used in the present study. The CAD was defined as the presence of angiographic coronary stenosis of $>50 \%$ of the luminal diameter in no less than one of the epicardial coronary arteries. Moreover, the prevalence and features of the coronary artery aneurysm/ ectasia among the cases with and without CAD were compared. Results: We observed coronary artery aneurysm (CAA) and ectasia (CAE) in $6.6 \%$ of the patients with significant CAD (+), and $6.1 \%$ of the patients with significant CAD $(-)(p=0.2)$. The percentage of coronary artery aneurysms was significantly higher in CAD $(+)$ patients than in CAD $(-)$ patients $(0.8 \%$ vs. $0.4 \%, p=0.015)$. The percentage of coronary artery ectasia showed no variation between CAD (+) patients and CAD (-) patients $(5.8 \%$ vs. $5.7 \%, p=0.47)$. The frequency of spotting aneurysm on a single coronary artery was higher than discerning aneurysm on two or three coronary arteries.

Conclusions: Presence of CAA or CAE cases is often encountered in those who have undergone angiography procedures. Furthermore, CAA and CAE should not be considered as simple dilations of vessels. Further studies are needed to determine the effective procedures for the treatment and prognostic evaluations of the patients with CAA or CAE.
\end{abstract}

Key words: coronary artery disease, aneurysm, ectasia.

\section{Introduction}

Coronary artery ectasia (CAE) has been defined as a diffuse dilatation exceeding more than a third of the coronary artery length, with the diameter of the ectatic segment 1.5 times greater than that of the adjacent normal segment [1-3]. On the other hand, coronary artery aneurysm (CAA), a rare clinical finding, is defined as a diffuse dilatation of

\section{Streszczenie}

Cel: Określenie częstości występowania i wpływu tętniaków lub rozstrzeni tętnic wieńcowych oraz ich korelacji z chorobą wieńcową (CAD).

Materiał i metody: Retrospektywnie oceniono wyniki koronarografii 6500 kolejnych dorosłych pacjentów, z których 418 spełniło kryteria włączenia do badania. Chorobę wieńcową zdefiniowano jako występowanie potwierdzonego angiograficznie zwężenia > 50\% średnicy światła w przynajmniej jednej nasierdziowej tętnicy wieńcowej. Ponadto porównano częstość występowania i cechy tętniaków lub rozstrzeni tętnic wieńcowych u pacjentów z chorobą wieńcową i bez niej.

Wyniki: Wśród pacjentów z istotną chorobą wieńcową częstość występowania tętniaków i rozstrzeni tętnic wieńcowych wyniosła $6,6 \%$, a wśród pacjentów bez istotnej choroby wieńcowej $6,1 \%(p=0,2)$. Występowanie tętniaków tętnic wieńcowych było znacząco częstsze wśród pacjentów z chorobą wieńcową niż wśród pacjentów bez tej choroby (odpowiednio $0,8 \%$ i $0,4 \%, p=0,015)$. Odsetek rozstrzeni tętnic wieńcowych we wspomnianych grupach był podobny (odpowiednio 5,8\% i 5,7\%, $p=0,47$ ). Zaobserwowane tętniaki częściej obejmowały jedną tętnicę wieńcową niż dwie lub trzy tętnice wieńcowe.

Wnioski: Obecność tętniaków lub rozstrzeni tętnic wieńcowych często obserwuje się u pacjentów poddanych zabiegom angiograficznym. Schorzeń tych nie należy traktować jako zwykłego poszerzenia naczynia. Potrzebne są dalsze badania, aby ustalić efektywne zabiegi lecznicze oraz rokowanie u pacjentów z rozstrzenią lub tętniakiem tętnicy wieńcowej. Słowa kluczowe: choroba wieńcowa, tętniak, rozstrzeń.

coronary arteries shorter than a third of the coronary artery length with a diameter 1.5 or more times larger than that of its normal contiguous segment $[1,4]$. When compared to CAE, CAAs involve a shorter segment of the coronary artery. The beginning and end points of CAAs are much sharper, and they are usually encountered as pathologies with larger diameters [5-7]. The prevalence of coronary artery

Address for correspondence: Dr Cengiz Ovalı, Cardiovascular Surgery Department, Medical Faculty, Eskisehir Osmangazi University, 26000 Eskisehir, Turkey, phone: 2222392979, fax: 2222392979, e-mail: drcengizovali@gmail.com

Received: 23.05.2017, accepted: 2.08.2017. 
ectasia is reported to be $0.3 \%$ to $5.3 \%$ in patients undergoing coronary angiography $[2-4,8]$. Likewise, the prevalence of CAA is reported to be between $1.5 \%$ and $4.9 \%$, with the right coronary artery (RCA) being the most affected one $[9,10]$. Underlying etiological factors for the development of both CAA and CAE show a remarkable similarity. The most common etiology for the development of CAE and CAA has been found to be atherosclerosis (50\%), which has also been found to be the most central factor in the development of coronary artery disease (CAD). Moreover, congenital impairments (20-30\%), inflammatory or vasculitis (10-20\%), and connective tissue disorders (5-10\%) are also among the etiological factors causing development of CAA $[8,11]$.
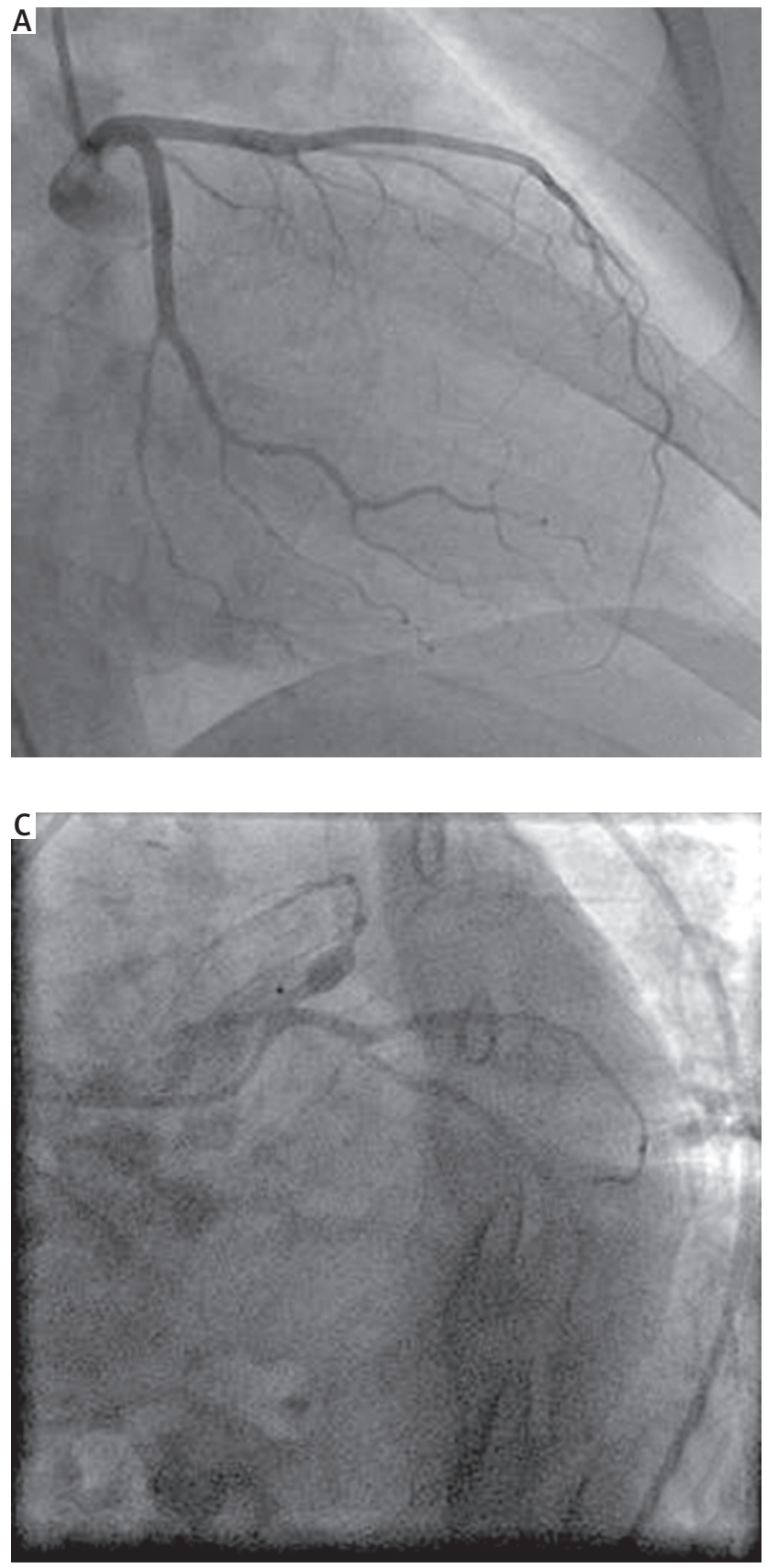

\section{Aim}

The present study attempts to evaluate association of CAD with the frequency and severity of CAA or CAE without considering clinical presentation type of the patients.

\section{Material and methods}

We retrospectively assessed the angiographic records of 6500 consecutive patients who underwent coronary angiography with any etiology between February 2008 and June 2010. Their angiographic movies were carefully reviewed by an expert. Initially, we mainly reviewed angiographic movies for the presence of coronary artery ectasia (Fig. 1 B) or aneurysm (Fig. 1 C). While the patients

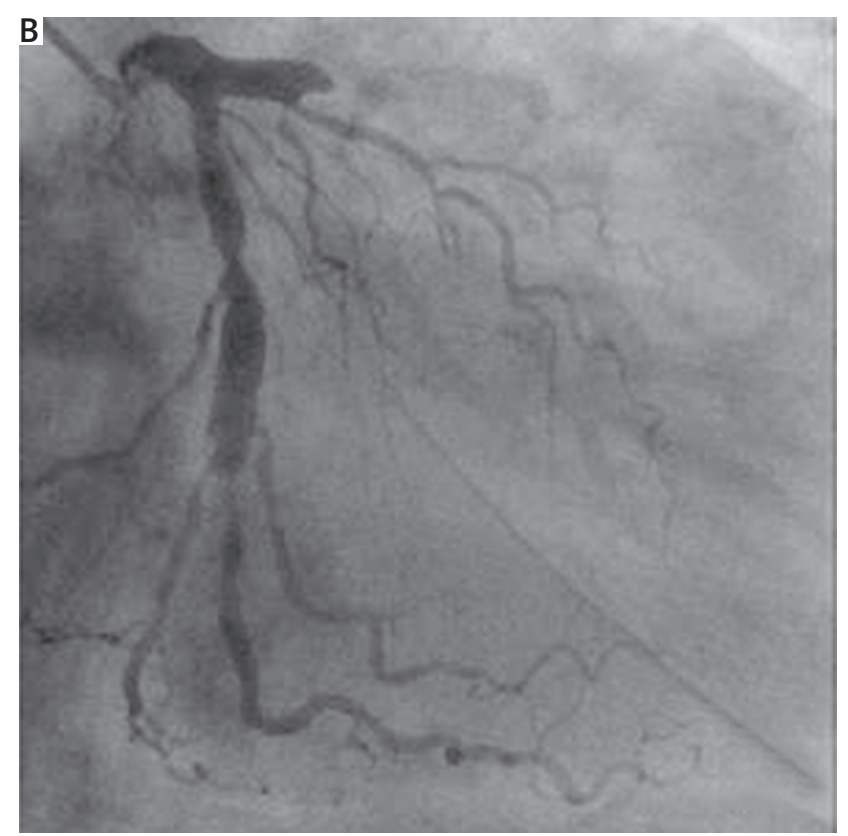

Fig. 1. Normal coronary artery (A), coronary artery ectasia (B) and coronary artery aneurysm (C) 
with a coronary artery possessing a diffuse dilatation exceeding more than a third of the coronary artery length, with the diameter of the ectatic segment 1.5 times greater than that of the adjacent normal segment, were assessed as CAE patients, those with a coronary artery having a diffuse dilatation shorter than a third of the coronary artery length, with a diameter of 1.5 or more times larger than that of its normal contiguous segment, were evaluated as CAA patients. Patients under the age of 18, cancer patients, pregnant patients, patients having no CAE or CAA, those who refused to participate in the study, and patients with poor digital angiographies were excluded from the study. Of the 6500 patients evaluated, only 418 patients showed CAE or CAA, and they were included in the present study. The analyses presented in the figures were obtained from the angiographic images of these patients. Based on the number of coronary arteries involved, the coronary ectasia and aneurysm were graded as mild if one coronary artery was involved but severe if two or more coronary arteries were involved. The location of ectasia and aneurysm was analyzed considering their isolated or combined location on various coronary arteries including the left main coronary artery (LMCA), left anterior descending artery (LAD), circumflex artery (Cx) and RCA. Coronary artery disease (CAD) was defined as the presence of at least $50 \%$ or more stenosis in one of the major coronary arteries. The patients were divided into two groups based on the presence of CAD. Subsequently, we evaluated the impact of CAD on the severity and the location of the ectasia or aneurysm.

\section{Statistical analysis}

Continuous variables were expressed as mean \pm standard deviation (SD); categorical variables were expressed as percentages. We used Student's t-test or the Mann-Whitney $U$ test, where appropriate, to compare continuous variables. Categorical variables were compared using the $\chi^{2}$ test. For all the tests, a value of $p<0.05$ was considered to be statistically significant. The SPSS statistical software package (SPSS, version 16.0 for Windows; SPSS Inc., Chicago, IL, USA) was used to perform all the statistical calculations.

\section{Results}

The review of the digital angiography records of 6500 patients (4227 CAD (+) and 2273 CAD (-)) showed that the mean age of the patients was $60 \pm 11$ years (range: 18101). Overall, the prevalence of aneurysm and ectasia was 418/6500 (6.4\%). We detected coronary artery aneurysm and ectasia in $6.6 \%$ of the CAD (+) patients and $6.1 \%$ of the CAD $(-)$ patients $(p=0.2)$. The percentage of coronary artery aneurysms was significantly higher in $C A D(+)$ patients than CAD $(-)$ patients $(0.8 \%$ vs. $0.4 \%, p=0.015)$. The percentage of coronary artery ectasia was similar between CAD (+) patients and $\mathrm{CAD}(-)$ patients $(5.8 \%$ vs. $5.7 \%, p=0.47)$. The frequencies of coronary artery aneurysm and ectasia considering the presence of CAD are summarized in Table I.

For aneurysms and ectasia, involvement of a single coronary artery was defined as mild, while their involvement of two or more coronary arteries were defined as severe. When the CAD (+) patients were compared with CAD (-) patients, the frequency of single coronary artery involvement for aneurysms and ectasia was higher than that of two or more coronary arteries. When the distribution of the CAA was examined for the present study population, $0.6 \%$ CAA was determined on a single coronary artery and $0.1 \%$ was found on two or more coronary arteries. Likewise, when the distribution of CAE was studied, 3.9\% CAE was observed on a single coronary artery and $1.8 \%$ was noted on two or more coronary arteries. While involvement of a single coronary vessel for CAA was found to be significantly higher in CAD (+) than CAD (-) patients $(0.7 \%$ vs. $0.2 \%, p=0.004)$, there was no significant difference between the groups for the involvement of two or more vessels for CAA $(p>0.05)$. While involvement of a single coronary vessel for CAE was found to be considerably higher in CAD (+) than CAD (-) patients ( $4.2 \%$ vs. $3.4 \%, p=0.075)$, there was no significant difference between the groups for the involvement of two or more vessels for CAE $(p>0.05)$. The results of coronary artery involvement for the present study population are summarized in Table II.

Frequency of CAE and CAA according to the coronary artery involvement was evaluated for each coronary artery. The CAA involvement was observed most commonly on the LAD artery, then on the RCA, and least on the Cx artery. Frequency of CAA according to the coronary artery involvement was comparable among the groups (except for the Cx artery) $(p>0.05)$. The frequency of CAA on the Cx artery was higher in the cases without CAD than those with CAD (0.2 vs. 0.0, $p=0.02$ ). Furthermore, CAE involvement was noted most frequently on the RCA, then on the $C x$, and least often on the LAD. Prevalence of CAE presence on the RCA was significantly greater in CAD (+) than CAD (-) (3.1\% vs. $1.8 \%, p=0.001)$. Moreover, frequency of CAE presence on the LAD-CX-RCA was slightly higher in CAD (-) compared to the CAD (+) patients, but the difference was not statistically significant $(1.1 \%$ vs. $0.7 \%, p=0.07)$. The results

Tab. I. Frequencies of coronary artery aneurysm and ectasia according to the presence of CAD

\begin{tabular}{lcccc} 
Parameter & Total $(n=6500)$ & CAD $(+)(n=4227)$ & CAD $(-)(n=2273)$ & P-value \\
Aneurysm, $n(\%)$ & $43(0.7)$ & $35(0.8)$ & $8(0.4)$ & 0.015 \\
\hline Ectasia, $n(\%)$ & $375(5.8)$ & $245(5.8)$ & $130(5.7)$ & 0.47 \\
\hline Aneurysm and ectasia, $n(\%)$ & $418(6.4)$ & $280(6.6)$ & $138(6.1)$ & 0.2 \\
\hline
\end{tabular}

CAD (+) - coronary artery disease-positive, CAD (-) - coronary artery disease-negative 
Tab. II. The effect of CAD on diffusiveness of coronary artery aneurysm and ectasia

\begin{tabular}{|c|c|c|c|c|c|}
\hline Parameter & & Total $(n=6500)$ & CAD (+) $(n=4227)$ & CAD $(-)(n=2273)$ & $P$-value \\
\hline \multirow[t]{3}{*}{ Aneurysm } & 1 vessel, $n(\%)$ & $36(0.6)$ & $31(0.7)$ & $5(0.2)$ & 0.004 \\
\hline & 2 vessels, $n(\%)$ & $1(<0.01)$ & $1(<0.01)$ & $0(0)$ & 0.65 \\
\hline & 3 vessels, $n(\%)$ & $5(0.1)$ & $2(<0.01)$ & $3(0.1)$ & 0.23 \\
\hline \multirow[t]{3}{*}{ Ectasia } & 1 vessel, $n(\%)$ & 255 (3.9) & $177(4.2)$ & $78(3.4)$ & 0.075 \\
\hline & 2 vessels, $n$ (\%) & $61(0.9)$ & $35(0.8)$ & $26(1.1)$ & 0.13 \\
\hline & 3 vessels, $n$ (\%) & $59(0.9)$ & $33(0.8)$ & $26(1.1)$ & 0.092 \\
\hline
\end{tabular}

CAD (+) - coronary artery disease-positive, CAD (-) - coronary artery disease-negative

Tab. III. Distribution of coronary artery aneurysm and ectasia detected on each coronary artery or on its branches

\begin{tabular}{|c|c|c|c|c|c|}
\hline Parameter & & Total $(n=6500)$ & CAD $(+)(n=4227)$ & CAD $(-)(n=2273)$ & $P$-value \\
\hline \multirow[t]{8}{*}{ Aneurysm } & LAD, $n(\%)$ & $14(0.2)$ & $12(0.3)$ & $2(0.1)$ & 0.08 \\
\hline & CX, n (\%) & $9(0.1)$ & $0(0)$ & $9(0.2)$ & 0.02 \\
\hline & RCA, $n(\%)$ & $10(0.2)$ & $7(0.2)$ & $3(0.1)$ & 0.5 \\
\hline & LAD-CX, $n(\%)$ & $0(0)$ & $0(0)$ & $0(0)$ & - \\
\hline & LAD-RCA, $n(\%)$ & $0(0)$ & $0(0)$ & $0(0)$ & - \\
\hline & CX-RCA, $n(\%)$ & $0(0)$ & $0(0)$ & $0(0)$ & - \\
\hline & LAD-CX-RCA, $n(\%)$ & $5(0.1)$ & $2(0.05)$ & $3(0.1)$ & 0.23 \\
\hline & LMCA, $n(\%)$ & $4(0.1)$ & $4(0.1)$ & $0(0)$ & 0.18 \\
\hline \multirow[t]{8}{*}{ Ectasia } & LAD, $n(\%)$ & $12(0.2)$ & $3(0.1)$ & $9(0.4)$ & 0.006 \\
\hline & CX, $n(\%)$ & $68(1)$ & $41(1)$ & $27(1.2)$ & 0.5 \\
\hline & RCA, $n(\%)$ & $170(2.6)$ & $129(3.1)$ & $41(1.8)$ & 0.001 \\
\hline & LAD-CX, $n(\%)$ & $17(3)$ & $8(0.2)$ & $9(0.4)$ & 0.1 \\
\hline & LAD-RCA, $n(\%)$ & $28(0.4)$ & $15(0.4)$ & $13(0.6)$ & 0.14 \\
\hline & CX-RCA, $n(\%)$ & $18(0.3)$ & $14(0.3)$ & $4(0.2)$ & 0.19 \\
\hline & LAD-CX-RCA, $n(\%)$ & $55(0.8)$ & $30(0.7)$ & $25(1.1)$ & 0.07 \\
\hline & LMCA, n (\%) & $3(<0.1)$ & $2(<0.1)$ & $1(<0.1)$ & 0.72 \\
\hline
\end{tabular}

CAD (+) - coronary artery disease-positive, CAD (-) - coronary artery disease-negative, LAD - left anterior descending artery, CX - circumflex artery, RCA - right coronary artery, LMCA - left main coronary artery

pertaining to the frequency of CAA or CAE considering the coronary artery involvement for each coronary artery are shown in Table III.

\section{Discussion}

A potential association between the presence of CAD and the development of CAA or CAE has not been investigated thoroughly enough so far. Therefore, the present study is an attempt to determine whether or not such a correlation exists. In the present study, the overall frequency of CAA or CAE was $6.4 \%$. The frequency of CAA was two-fold higher in CAD (+) patients than CAD (-) patients. By contrast, the prevalence of CAE was comparable between the CAD (+) and CAD (-) patients.

The data available in the literature as regards the frequency of CAA in the human population were collected and reported on the patients who underwent coronary angiography due to suspected coronary artery disease. Previous studies have shown the frequency of CAA to be between 0.3 and $5 \%[5,12-15]$. In the current study, the prevalence of CAA was slightly lower (0.7\%) than the prevalence reported in the literature, which we assume could be accounted for by a number of factors. One of the factors is the difference in the evaluation of CAA and CAE. While earlier studies evaluated CAA and CAE together and provided no distinct definition of them $[5,9,16]$, in the present study we did distinguish CAA from CAE. Another reason for the lower frequency of CAA could be associated with differences in the patient population involved in the present and previous studies. The data on CAA in different countries were usually obtained during coronary angiographies that were performed on patients with suspected coronary artery disease. When the effect of genetic differences and presence of atherosclerosis are considered for the development of CAA, no differences in frequencies of CAA are expected to be observed in different regions of the world. On the other hand, detection of two-fold higher frequency of CAA in the CAD (+) cases compared to CAD (-) is an expected observation, seeing that atherosclerosis is the most significant determining factor underlying the development of CAA and CAD $[15,17]$.

We noted that the prevalence of CAE was nine-fold higher than that of CAA in the present study. The CAE is 
a relatively common angiographic finding with an average prevalence of $1-5 \%$ [18-20]. The prevalence of CAE in the current study was slightly higher (5.8\%) than that in the literature. One factor leading to the present finding might be the approach used in the evaluation of CAE. When angiographic records with critical coronary artery diseases in the earlier studies were evaluated, slight CAEs might have been ignored and hence not reported; therefore, this point should be considered for the reports based solely on the angiographic reports. While the present study is also a retrospective study, we additionally evaluated angiographic videos, not only the records for the study of CAA or CAE.

Most of the patients included in the present study were those who underwent coronary angiography due to suspected CAD. The current measurements showed that $65 \%$ of our patients had severe CAD that narrowed more than $50 \%$ of the vessel's lumen. The majority of the remaining patients probably had CAD as well, though not resulting in noticeable narrowing. Histopathological and epidemiological studies performed to reveal physiopathological factors underlying the development of CAE indicate that similar physiopathological mechanisms for CAD are also responsible for the progression of CAE [21, 22]. Since most of our patients had CAD, this might result in their having a relatively high prevalence of CAE. Therefore, when the results of such studies are evaluated, the cause and effect relation should also be considered.

We also observed similar frequency for CAE in the angiographies of the patients with or without CAD. This is an unexpected finding when we consider that similar etiological factors are responsible for the development of CAD and CAE. This could be due to the fact that the patients with CAD causing less than $50 \%$ of luminal narrowing are not considered as CAD (+). Further studies involving patients with mild atherosclerosis problems are needed for the clarification of subtle points like this.

Assessment of angiographic series performed on patients with CAD prediagnosis has shown CAE to most commonly involve the RCA $[9,23]$. Likewise, CAE involvement was noted most frequently on the RCA, then on the $C x$, and least frequently on the LAD in the present study. Correspondingly, development of CAE should not be considered an innocent dilation of a coronary vessel. An increasing number of recent studies have shown that, contrary to popular belief, CAE is not a benign progress. Rather, histological examinations of ectatic vessels have shown that their tunica media are impaired and so they are prone to spasm [24]. Furthermore, earlier studies show that coronary blood flow becomes slower in ectatic arteries and development of ischemia could be attributed to a decreased blood flow rate [25]. A more recent study revealed that epicardial and microvascular perfusions are also compromised in patients with CAE [26]. Presence of a dilated section in an ectatic vessel causes swirling blood flow, and patients with $C A E$ can present typical effort angina although there exists no accompanying CAD. This can result in the formation of a number of complications beyond the site of CAE, includ- ing recurrent microemboli and thrombotic occlusion of the dilated section [27, 28].

By contrast to CAD, the approach for the treatment of CAA and CAE has failed to be established well enough so far. The treatment of CAA and CAE, when accompanied by $C A D$, is similar to that of patients with only CAD. The prognosis for patients with isolated CAE accompanied by CAD is considered to be better, and putting the patients on aspirin as an antiaggregant agent could be sufficient [29]. Unfortunately, there is a limited amount of data available on the prognosis of CAE in the literature. While some studies indicate that CAE has a similar prognosis to CAD, others claim that they have comparable prognoses as with the normal population [12, 30].

The major limitations of the present study can be listed as follows: 1 . It is a retrospective study. 2. It was conducted on patients who underwent coronary angiography for suspected coronary artery disease. Therefore, the present study does not provide actual information concerning the in situ frequency of CAE and CAE in the general population. Even so, the present study can give us some idea about the frequency of CAE and CAE.

\section{Conclusions}

We often encounter cases of CAA and/or CAE in patients receiving angiography, and they are frequently recognized as simple enlargements of coronary arteries; however, neither CAA nor CAE should be considered as simple dilation of vessels, since it might result in significant cardiovascular complications such as rupture, thrombosis and embolization. In conclusion, further studies are needed to accurately determine effective procedures for the treatment and prognostic evaluation of patients diagnosed with CAA or CAE.

\section{Disclosure}

Authors report no conflict of interest.

\section{References}

1. Luo Y, Tang J, Liu X, Qiu J, Ye Z, Lai Y, Yao Y, Li J, Wang X, Liu X. Coronary artery aneurysm differs from coronary artery ectasia: angiographic characteristics and cardiovascular risk factor analysis in patients referred for coronary angiography. Angiology 2016; 68: 823-830.

2. Yilmaz H, Sayar N, Yilmaz M, Tangürek B, Cakmak N, Gürkan U, Gül M, Şimşek D, Bolca O. Coronary artery ectasia: clinical and angiographical evaluation. Turk Kardiyol Dern Ars 2008; 36: 530-535.

3. Rukhsan S, Nuzhat S, Ishaq M, Samad A. The prevalence and clinical profile of angiographic coronary ectasia. J Pakistan Med Assoc 2011; 61: 372-375.

4. Demopoulos VP, Olympios CD, Fakiolas CN, Pissimissis EG, Economides NM, Adamopoulou E, Foussas SG, Cokkinos DV. The natural history of aneurysmal coronary artery disease. Heart 1997; 78: 136-141.

5. Swaye PS, Fisher LD, Litwin P, Vignola PA, Judkins MP, Kemp HG, Mudd JG, Gosselin AJ. Aneurysmal coronary artery disease. Circulation 1983; 67: 134-138.

6. Swanton RH, Thomas ML, Coltart DJ, Jenkins BS, Webb-Peploe MM, Williams BT. Coronary artery ectasia - a variant of occlusive coronary arteriosclerosis. Br Heart J 1978; 40: 393-400.

7. Befeler B, Aranda MJ, Embi A, Mullin FL, El-Sherif N, Lazzara R. Coronary artery aneurysms: study of the etiology, clinical course and effect on left ventricular function and prognosis. Am J Med 1977; 62: 597-607.

8. Morrad B, Yazici HU, Aydar Y, Ovali C, Nadir A. Role of gender in types and frequency of coronary artery aneurysm and ectasia. Medicine 2016; 95: e4395. 
9. Syed M, Lesch M. Coronary artery aneurysm: a review. Prog Cardiovasc Dis 1997; 40: 77-84.

10. Hartnell GG, Parnell BM, Pridie RB. Coronary artery ectasia. Its prevalence and clinical significance in 4993 patients. Br Heart J 1985; 54: 392-395.

11. Iannopollo G, Ferlini M, Koziński M, Ormezzano MF, Crimi G, Lanfranchi L, Camporotondo R, Visconti LO, De Ferrari GM, De Servi S. Patient outcomes with STEMI caused by aneurysmal coronary artery disease and treated with primary PCI. J Am Coll Cardiol 2017; 69: 3006-3007.

12. Markis JE, Joffe CD, Cohn PF, Feen DJ, Herman MV, Gorlin R. Clinical significance of coronary arterial ectasia. Am J Cardiol 1976; 37: 217-222.

13. Munker TM, Peterson O, Vesterdal J. Congenital aneurysm of the coronary artery with an arteriovenous fistula. Acta Radiol 1958; 150: 333-336.

14. Daoud AS, Parkins D, Tulgan H, Floreutin RA. Aneurysms of the coronery artery: report of ten cases and review of literature. Am J Cardiol 1963; 11: 228-237.

15. Crawley PD, Mahlow WJ, Huntsinger DR, Afiniwala S, Wortham DC. Giant coronary artery aneurysms: review and update. Tex Heart Inst J 2014; 41: 603-608.

16. Boyer N, Gupta R, Schevchuck A, Hindnavis V, Maliske S, Sheldon M, Drachman D, Yeghiazarians $Y$. Coronary artery aneurysms in acute coronary syndrome: case series, review, and proposed management strategy. J Invasive Cardiol 2014; 26: 283-290.

17. Dahhan A. Coronary artery ectasia in atherosclerotic coronary artery disease, inflammatory disorders, and sickle cell disease. Cardiovasc Therap 2015; 33: 79-88.

18. Pinar Bermúdez E, López Palop R, Lozano Martínez-Luengas I, Cortés Sánchez R, Carrillo Sáez P, Rodríguez Carreras R, Picó Aracil F, Valdés Chávarri M. Coronary ectasia: prevalence, and clinical and angiographic characteristics. Rev Esp Cardiol 2003; 56: 473-479.

19. Sultana R, Sultana N, Ishaq M, Samad A. The prevalence and clinical profile of angiographic coronary ectasia. J Pakistan Med Assoc 2011; 61: 372-375.

20. Harikrishnan S, Krishnakumar N, Jaganmohan T. Coronary artery ectasia is it time for reappraisal? Clin Cardiol 2007; 10: 536
21. Sudhir K, Ports TA, Amidon TM, Goldberger JJ, Bhushan V, Kane JP, Yock P, Malloy MJ. Increased prevalence of coronary ectasia in heterozygous familial hypercholesterolemia. Circulation 1995; 91: 1375-1380.

22. Grönke S, Diet F, Kilter H, Böhm M, Erdmann E. Characteristics of patients with coronary ectasias with and without stenotic coronary artery disease. Dtsch Med Wochenschr 2005; 130: 2375-2379.

23. Yip HK, Chen MC, Wu CJ, Hang CL, Hsieh KY, Fang CY, Yeh KH, Fu M. Clinical features and outcome of coronary artery aneurysm in patients with acute myocardial infarction undergoing a primary percutaneous coronary intervention. Cardiology 2002; 98: 132-140.

24. Bove AA, Vlietstra RE. Spasm in ectatic coronary arteries. Mayo Clin Proc 1985; 60: 822-826.

25. Papadakis MC, Manginas A, Cotileas P, Demopoulos V, Voudris V, Pavlides G, Foussas SG, Cokkinos DV. Documentation of slow coronary flow by the TIMI frame count in patients with coronary ectasia. Am J Cardiol 2001; 88: 1030-1032

26. Güleç S, Atmaca Y, Kılıçkap M, Akyürek O, Aras O, Oral D. Angiographic as sessment of myocardial perfusion in patients with isolated coronary artery ectasia. Am J Cardiol 2003; 91: 996-999.

27. Al-Harthi SS, Nouh MS, Arafa M, Al-Nozha M. Aneurysmal dilatation of the coronary arteries: diagnostic patterns and clinical significance. Int J Cardiol 1991; 30: 191-194.

28. Rab ST, Smith DW, Alimurung BN, Rab R, King SB $3^{\text {rd }}$. Thrombolytic therapy in coronary ectasia and acute myocardial infarction. Am Heart J 1990; 119: 955-957.

29. Yetkin E, Waltenberger J. Novel insights into an old controversy: is coronary artery ectasia a variant of coronary atherosclerosis? Clin Res Cardiol 2007; 96: 331-339.

30. Harikrishnan S, Sunder KR, Tharakan J, Titus T, Bhat A, Sivasankaran S, Francis B. Coronary artery ectasia: angiographic, clinical profile and follow-up. Indian Heart J 2000; 52: 547-553. 